\title{
Who Did What When? Acknowledging Collaborative Contributions in Digital History Projects
}

Qui a fait quoi quand? Reconnaitre les contributions collaboratives dans les projets d'histoire numérique

¿Quién hizo qué cuándo? Reconocer las contribuciones colaborativas en los proyectos de historia digital

Quem fez o quê quando? Reconhecer as contribuições colaborativas nos projetos de história digital

Henry B. Lovejoy

\section{CpenEdition} Journals

Electronic version

URL: http://journals.openedition.org/slaveries/2717

DOI: $10.4000 /$ slaveries. 2717

ISSN: 2540-6647

Publisher

CIRESC

Electronic reference

Henry B. Lovejoy, «Who Did What When? Acknowledging Collaborative Contributions in Digital History Projects », Esclavages \& Post-esclavages [Online], 3 | 2020, Online since 27 November 2020, connection on 10 December 2020. URL : http://journals.openedition.org/slaveries/2717 ; DOI : https://doi.org/ $10.4000 /$ slaveries. 2717

This text was automatically generated on 10 December 2020.

Les contenus de la revue Esclavages \& Post-esclavages / Slaveries \& Post-Slaveries sont mis à disposition selon les termes de la licence Creative Commons Attribution - Pas d'Utilisation

Commerciale - Pas de Modification 4.0 International. 


\title{
Who Did What When?
}

\section{Acknowledging Collaborative Contributions in Digital History Projects}

\author{
Qui a fait quoi quand? Reconnaître les contributions collaboratives dans les \\ projets d'histoire numérique \\ ¿Quién hizo qué cuándo? Reconocer las contribuciones colaborativas en los \\ proyectos de historia digital \\ Quem fez o quê quando? Reconhecer as contribuições colaborativas nos projetos \\ de história digital
}

Henry B. Lovejoy

1 As digital publications gain more traction, issues arise related to best practices of citing the contributors to major research initiatives. This project history explores Liberated Africans (www.liberatedafricans.org) to evaluate how to provide individual recognition within highly collaborative, database-driven archival repositories. The original website was built using HTML and first launched on 6 August 2015. It has since expanded into an interdisciplinary collaboration with support from different academic institutions and granting agencies. This article explains the second version relaunch of Liberated Africans on 15 March 2018, which involved improving the backend for searchability. The overarching aim of Liberated Africans is to retrace the lives of approximately 225,000 enslaved Africans taken off slave ships in British-led campaigns to abolish the slave trade between 1807 and 1896. As more and more scholars piece back together activities of some of the world's earliest international courts of humanitarian effort, crediting individual participation in a digital project has become an issue, especially as roles sometimes become defined, redefined and refined over the natural evolution of website development. 
2 The challenge of acknowledging credit within digital projects has implications for tenure and promotion, or indeed landing that highly competitive job. As Joseph Raben (2007) points out "the status of online publication as an inferior medium is probably the concern on the part of potential contributors... (and) not as highly regarded by the gatekeepers of tenure and promotion as the traditional hard-bound book and the article offprint". Unlike print publications, digital projects might never end because they continuously transform over time. Matthew G. Kirschenbaum (2009) raises the question: "What does it mean to 'finish' a piece of digital work?". The answer is not always obvious because the measure of academic success revolves around "the pressure of milestones, deadlines, deliverables and products (as opposed to projects)". Since most digital research is interdisciplinary, keeping track of contributions calls attention to varying levels of involvement at key benchmarks. As many digital collaborators realize, the role of any number of people in advancing a digital project can in essence be much more abstract and obscure (Posner 2016). After all, where does one give credit and who decides how to give it? As both a data repository and digital archive, Liberated Africans did not simply begin at its inaugural launch in 2015, but builds upon decades of digitally-based research related to the history of Africa and the African diaspora dating back to the 1960s.

This paper aims to outline problems in acknowledging individual contributions, and examines how digital projects in the field of Africa and the African diaspora history have been addressing best practices. It provides one example of how to credit the many participants in Liberated Africans, who either deliberately or inadvertently influenced its success. Recognizing all levels of involvement requires supplementary publications to strengthen its value as academic research and promote academic integrity. ${ }^{1}$ Beyond decades of research published on paper, the creation of Liberated Africans would not be possible without well-established, open-access and crowd-sourced websites. This type of research demands explanations of which participants contributed what materials and when. Project histories, such as the one embedded in the forthcoming discussion, provide a basis for assessing individual participation for tenure, promotion and the job market.

\section{Digital historiography of the African diaspora}

In 1969, Philip Curtin first raised fundamental questions about when and where people came from in Africa; and when and where they went in the transatlantic slave trade. His early research "brought together bits and pieces of incommensurate information" related to "the measurable number of people brought across the Atlantic". At a time when computers were emerging into the mainstream, Curtin argued that "the social sciences [were] becoming more quantitative". He also recognized how the historiography was "full of estimates that seem to agree to the range (of) fifteen to twenty-five million slaves landed in the Americas". Using statistical methods and his broad knowledge of the field, Curtin conservatively predicted that future research would reduce that range to 10.5 million departures and 8 million arrivals. He acknowledged that his inquiry was a starting point because "better data on the numbers carried by the trade at particular times should make it possible to project the annual flow of slaves from particular societies" (1969, xvi and 273). Meanwhile, Herbert S. Klein and "other [unidentified] scholars" collected data on slave-trading voyages and 
began coding them "into a machine-readable format" (Eltis 2018c). In the 1970s, David Eltis, inspired by Curtin and Klein, began compiling information more systematically into SPSS about illegal slaving voyages after British abolition in 1807. Eltis also created the "African Names Database," which amounts to a spreadsheet of over 68,000 Liberated Africans registered by Vice Admiralty Courts and Mixed Commissions in Sierra Leone, Cuba and St. Helena (Eltis 1977; Eltis 1982; Eltis 1986; Eltis 1987).

5 By 1990, Eltis met Stephen Behrendt at the Public Record Office in Chancery Lane, which subsequently moved to Kew in 2003 and was renamed The National Archives. They quickly realized they were gathering complementary data about slaving voyages between 1785 and 1807 (Behrendt 1988; Behrendt 1993). In the spirit of collaboration, they decided to put "everything together on a CD-ROM", which was not a cheap technological proposition at the time. Two years later, Eltis and Behrendt approached Henry Louis Gates Jr. with their idea; he then gave them an office and support at Harvard University's W. E. B. Du Bois Institute for African and African American Research (now the Hutchins Center). The National Endowment for the Humanities (NEH) and the Andrew J. Mellon Foundation supported this pioneering effort. Over the next decade, Eltis and Behrendt brought David Richardson on board because he had amassed materials for British voyages leading up to 1785, especially for the port of Bristol. By 1999, The Trans-Atlantic Slave Trade: A Database on CD-ROM was released with data for over 27,000 voyages. It was highly acclaimed, but full of gaps, and more people began to contribute data from archives in Africa, Europe and the Americas. With even more support from NEH and Harvard, a revised and expanded second edition of the database on CD-ROM came out in 2008. Soon after that, CD-ROM became obsolete and the project migrated out of Harvard onto servers at Emory University where it was rebranded Voyages: The Trans-Atlantic Slave Trade Database (Williford 2010).

Since going online, Voyages has received more funding for various recoding updates, a Portuguese translation, pedagogical resources, samples of archival materials, data visualization tools (graphs, tables, charts, etc.) and an animated map illustrating some 36,000 voyages crossing the Atlantic to various destinations in the Americas, Africa and Europe (Kahn \& Bouie 2015). ${ }^{2}$ Statistically, Voyages revises Curtin's preliminary estimates upwards, so that now the data substantiate that approximately 12.5 million people were forced onto slave ships along the African coast, while only about 10.7 million reached the Americas due to mortality rates (Eltis et al. 2018b). ${ }^{3}$ Meanwhile, the "African Names Database" has expanded to over 90,000 Liberated Africans and has formed the basis of African Origins, which is a platform that crowd-sources interpretations of the languages of transliterated African names to assess the ethnolinguistic composition of the slave trade after 1807 (Nwokeji \& Eltis 2002a; Nwokeji \& Eltis 2002b; Eltis et al. 2018a). By 2009, I had transcribed registers compiled in Cuba and the Caribbean independently from Eltis and noticed inconsistencies with the transcription of the Havana registers. These changes have since been absorbed into African Origins (H. Lovejoy 2009). A year later, Suzanne Schwarz and Paul Lovejoy identified and began digitizing previously unincorporated materials from the Vice Admiralty Court in Freetown for 1808-1819 through support from the British Library Endangered Archives Programme. Since then, Schwarz, Paul Lovejoy, Eltis, Richard Anderson, Daniel Domingues da Silva, Philip Misevich, Olatunji Ojo, and Alex Boruki began taking stock of the various copies of the registers of Liberated Africans disembarked at Freetown held in archives in England and Sierra Leone (Anderson et al. 
2013). Revisions to the total sample of registers have since occurred under the direction of Eltis and Misevich.

7 As Voyages and African Origins continue to evolve, with an upgrade of the former released in 2019, the issue about who contributed what and when remains fuzzy. As is standard practice on digital projects now, both websites list sponsoring organizations and institutions, as well as dozens of contributors grouped into categories. The preand post-2019 version of Voyages included "Principal Investigators", "Project Team", "Steering Committee", and "Advisory Board". There is also an additional page called "Contributors of Data", which alphabetically listed nearly sixty people who had contributed data "since the publication of the 1999 CD-ROM" (Eltis et al. 2018a; Eltis et al. 2018b). ${ }^{4}$ However, problems remain with this approach. How does this list-based standard demarcate specific contributions? Why would a tenure or promotion committee seriously assess someone in an alphabetical list without knowing how, what and when they contributed under the direction of a prominent scholar? And how does this loose practice help younger generations receive tangible credit for their research donations to a larger collective? While these groupings certainly provide degrees of recognition, the ambiguity fails to recognize credit adequately, and might to some degree disincentivize others from making more contributions. Featuring in such lists is arguably akin to being mentioned in the acknowledgments of a published monograph or in the first footnote of a peer-reviewed article-neither of which mentions would ever appear on a $\mathrm{CV}$, let alone enter the discussion of tenure, promotion or job interviews.

8 Eltis has recognized the problem of assigning credit within digital projects. On the 2018 Voyages "Acknowledgements" page, an anonymous author (most likely Eltis) included a sub-section called "Special Thanks", which states:

Many people contributed to the successful completion of this project-enough that we fear in our attempts to acknowledge them, we may only call attention to having forgotten someone and their worthy assistance in our efforts. With apologies for any regrettable omissions and our sincerest thanks to everyone, named or anonymous, who graciously gave their time and expertise. (Eltis 2018b)

9 Likewise, on the "About Project" page of African Origins, another anonymous author (probably Eltis) explained how "many individuals supported the work of the project and the project team, [but they are] too numerous to name here" (Eltis 2018a). My contribution to over 10,000 rows of data appears only as "Havana Register Research," which involved months of work required to transcribe the Havana registers, as well as working with Ojo, Abubakar Babajo Sani and Umar Hussein to interpret nearly 4,000 African names, which were then inputted one at a time into African Origins in 2013. The way in which these contributions are presented on Eltis' website would give little credence to support a case for tenure or promotion.

Eltis has not been the only scholar to encounter the issue of assigning credit to successful digital projects. In 2001, Jerome S. Handler and Michael Tuite launched Atlantic Slave Trade and Slave Life in the Americas: A Visual Record (Handler \& Tuite 2018: www.slaveryimages.org). In the project's history, Handler explains how this website began as a collection of images for use in an undergraduate anthropology course at Southern Illinois University, Carbondale "in the late 1980s and early 1990s". This image archive was intended to show "everyday life of enslaved Africans and their descendants in the Americas". In attempts "to illustrate every lecture", Handler engaged staff at the university's Learning Resources Services to produce slides of well-known images of 
slavery. At a NEH Summer Institute for college teachers at the Virginia Foundation for the Humanities in 1998, Handler presented those slides whereby he recalls how "someone... probably [Joseph] Miller or a student... suggested that the whole slide collection should be scanned/digitized".

But who were the people who made those early slides and who really came up with the idea of putting the images online? Should they not receive recognition too? Handler seems to think so because he makes an effort to assign credit to those specific ideas and contributions that were not his. Much like Voyages, the history of this image archive clearly has inconsistencies due to what Handler explains as "memory issues" (2018). The website, which used PHP, went live in September 2000 with only 150-200 images. Michael Tuite, the then director of the Multimedia Resource Center at the University of Virginia (now Robertson Media Center and Digital Lab), scanned and digitized the images and helped Handler develop a backend system. The project has since expanded to over 1,200 images. Despite the lack of specific names, Handler's project history has been maintained since I assumed the website's directorship in 2018, renaming the site Slavery Images: A Visual Record of the African Slave Trade and Slave Life in the Early African Diaspora. Brumfield Labs re-coded and relaunched the website using Omeka-S and International Image Interoperability Framework (IIIF) on 15 January 2019.

\section{Digitizing world archives}

In the 1990s, the digital camera became affordable, and hence data retrieval more accessible and processing much easier. Since then, numerous institutions, granting agencies and private funds have supported the mass digitization of primary source collections from archives around the world. The immeasurable amount of material currently available in digital format, with much more to follow, has rapidly and steadily been appearing online through different institutional websites, including the British National Archives and the British Library, as well as independent digital projects such as Liberated Africans. Arguably, the people doing the digitizing work do not always get the full credit they deserve. Generally, the task is perceived as nonanalytical and "service" because it involves taking pictures of documents volume-byvolume, page-by-page. Truth be told, digitization efforts require much more recognition than simply being "service." The researcher has to identify and justify what collection needs duplicating, assess if any digitization work has already been done, determine if the archive permits photography, apply and wait for funding, hire and train research assistants, organize travel to the archive, take the time to photograph records, secure copyright, prepare the files for online publication, create inventories, develop metadata and ingest files into a content management system for public consumption. Jane Landers, a full professor, has received extensive credit for organizing research teams involved in digitizing over 700,000 images mostly from ecclesiastical and secular sources in slave societies related to approximately 6-8 million Africans and their descendants in the Americas. Her website conveys, quite clearly, who did what and when, including the numerous research assistants on numerous teams oftentimes, but not always, under her direction (Landers et al. 2018). Nevertheless, would this digital project be enough to get someone tenure or a promotion? Probably not at present in most history departments, despite the ramifications Landers' massive digital project will have throughout the field of Atlantic 
world history, as well as for the ancestry of Africans and their descendants, for generations to come.

Liberated Africans would not be possible if not for the Public Record Office and The National Archives which undertook the "Digital Microfilm Project" (2018). The current digital director explains how this initiative "became a 'first generation' digital archive: one that adopts a traditional, paper-based approach to selecting, preserving and providing access to records and replicates it as closely as possible using digital technology" (Sheridan 2017). Over several decades, dozens of collections were microfilmed, which were then converted into PDF formats around 2011 and 2012. Liberated Africans has been reorganizing on a document-by-document basis these digitized records from the Foreign Office 84 series called "Slave Trade Department and Successors: General Correspondence before 1906". This collection amounts to over 2,200 downloadable volumes containing thousands of individual documents (FO 84). At present, the National Archives does not provide much more explanation about the Digital Microfilm Project. A rather vague project history was obtained only after asking through email, chat rooms, telephone calls and by submitting a Freedom of Information request. Liberated Africans owes much to unidentified teams of people involved in this major digitization effort at the archive, which spanned several decades in two locations.

14 The British Library's "Endangered Archives Programme," established in 2004, preserves collections held in world archives that are at risk of being destroyed, and puts them in the public domain (Anon. 2015). Liberated Africans leverages digitized materials from the Sierra Leone Public Archives. Under the direction of Paul Lovejoy and Schwarz over the course of three grants, this preservation taskforce has duplicated over 270 volumes and 75,000 images (EAP 2009; EAP 2011; EAP 2015). The Chief Government Archivist in Sierra Leone, Albert Moore, oversaw the project on site, while digitization efforts involved Alfred Fornah, Abu Koroma and Aiah Yendeh. As best practice, Paul Lovejoy explains how "each digital file contains information about who digitized what and when". ${ }^{5}$ Because of infrastructure difficulties in the archives, all images were checked, metadata prepared, and an inventory compiled, initially by Diane Lee, a librarian, at the Harriet Tubman Institute for Research on Africa and Its Diasporas at York University. In January 2017, Bruno Véras, a PhD student at York, took over this responsibility, but more project managers will likely follow. ${ }^{6}$

Liberated Africans hosts digital primary sources from personal archival collections, which oftentimes stem from years of research. For example, I digitized materials located in Barbados, Brazil, Cuba, Curaçao, France, the Netherlands, Spain, Suriname, and Great Britain between 2001 and 2014. Before, during and after my dissertation, I was employed as a research assistant on NEH and Endangered Archives Programme grants, as well as being awarded grants, fellowships and travel stipends through various institutes and departments at the University of California Los Angeles, Universities of California-Cuba Academic Initiative, Fulbright-Hays, Tabor Foundation, the Social Sciences and Humanities Research Council of Canada (SSHRC), Harvard, NEH and the Mellon Foundation. The material that was collected is openly shared with other scholars, and much of the relevant records now appears on Liberated Africans, most especially a complete copy of the registers of Liberated Africans from the FO313 series, "Archives of the Havana Slave Trade Commission". Beyond my own contributions, Liberated Africans also uses materials from the personal collections digitized by (in order 
of general importance): Richard Anderson, Suzanne Schwarz, Paul Lovejoy, Daniela Cavalheiro, Marial Iglesias Utset, Inés Roldán Montaud, Jorge Felipe and Sean Kelley. ${ }^{7}$ As best practices, Liberated Africans compiles primary source inventories that attempt to reference who digitized what and when according to DublinCore standards.

\section{Digital project creation and development}

Liberated Africans grew out of the environment of the highly competitive academic job market. Following a SSHRC postdoctoral fellowship, I enrolled in a certificate program, "Digital/Multimedia and Information Resource Design," at Seneca College in Toronto in the winter of 2015. The idea of Liberated Africans was born while learning how to code HTML, CSS and JavaScript and use Adobe Creative Cloud. Using a Bootstrap framework and hosted on GoDaddy, I put most of my dissertation research online. The initial website had over sixty individual HTML webpages, centered on forty-four trials involving over 10,000 Africans liberated by the Havana Slave Trade Commission between 1824 and 1841 (Lovejoy 2009). A copyright license was obtained from the British National Archives to republish their digital records online, which were then rearranged into their respective cases involving over 750 documents, including: register copies, trial abstracts, captor declarations, expense reports, resettlement strategies, legislation, etc. Each case-page had a summary, map, database, table and graph. There were other data visualizations and analyses for the demographics of the total sample; and an "Image Gallery" with over 150 prints, paintings, photographs, and sketches of ships, barracoons, and Liberated Africans, which mainly derive from Handler's collection in Slavery Images. Other paintings, prints, sketches and photographs were harvested from the British National Maritime Museum, British National Archives, and Brazil's Biblioteca Digital da Fundação Biblioteca Nacional. The original website also incorporated images digitized by myself, Richard Anderson, Daniela Cavalheiro and Daryle Williams. Using Premier Pro, I also made a mini documentary about the Havana Slave Trade Commission (see below). Francis Otero consulted extensively on the short film and original website design (Figure 1).

This media file cannot be displayed. Please refer to the online document http:// journals.openedition.org/slaveries/2717 
Figure 1. Components of the initial Liberated Africans website design (15 August 2015)

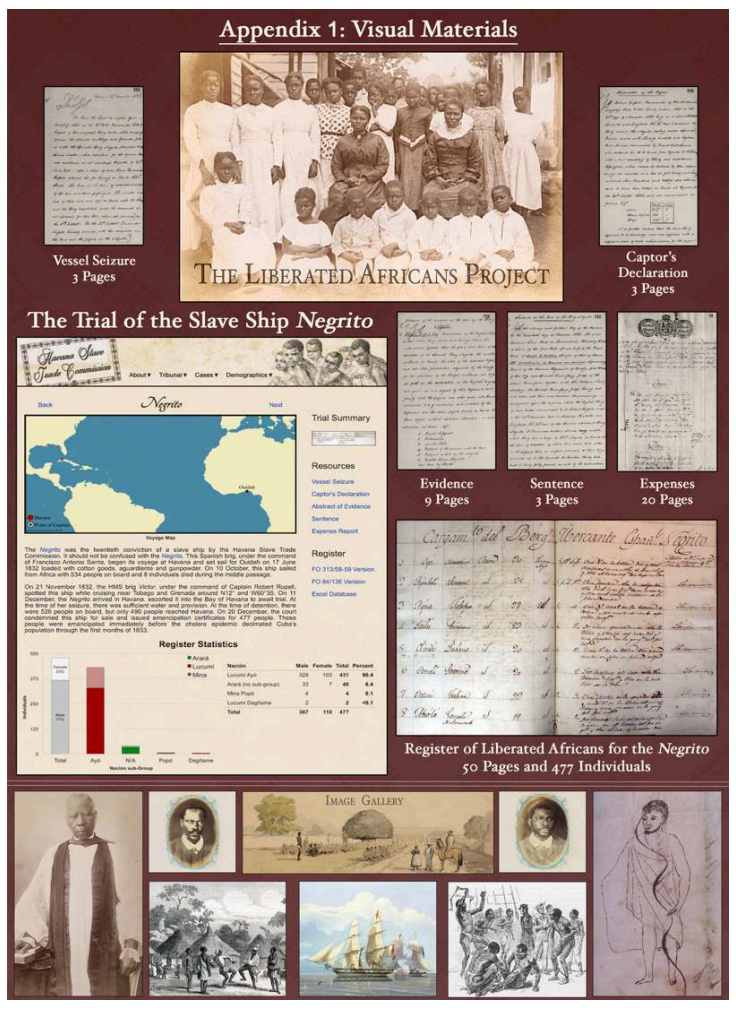

The URL liberatedafricans.org circulated rapidly shortly after it was released in August 2015. Iglesias Utset invited me to present the digital project at a conference called "New Research on the Atlantic Slave Trade" at Harvard University on 2-3 October 2015. In preparation for the event, Anderson, Cavalheiro, Eltis, Schwarz and Williams were invited to join the initiative due to their expertise on the courts and cases in Sierra Leone and Brazil. Anderson and Williams submitted one case summary each to me for Freetown and Rio de Janeiro, including sample PDFs of case files. They also created preliminary case lists, which involved selections of data from Voyages. Test cases for Sierra Leone and Brazil were then hard coded into Liberated Africans, while a new homepage was being developed and the website's structural hierarchy expanded. To support this initiative, Henry Louis Gates, Jr., director of the Hutchins Center at Harvard, awarded me a $\$ 50,000$ subvention grant publicly during the conference. After, Anderson and Williams were appointed co-principal investigators on this grant with support from Matrix: The Center for Digital Humanities \& Social Sciences at Michigan State University.

Once Liberated Africans migrated to servers at Matrix, the next phase required that the website be re-coded for searches and prepared for the ingestion of more data related to the global abolition movement. Over the next two years, Anderson, Williams, Dean Rehberger, Alicia Sheill, oftentimes Catherine Foley, and occasionally Walter Hawthorne and Ethan Watrall assisted in the transformation of an HTML website into a more complex digital vehicle. To define the controlled vocabulary, Matrix hosted two in-person meetings in East Lansing on 3-5 November 2015 and 26-29 July 2017. Between these two meetings, the project team met monthly to discuss the website's metadata structure in order for it to operate with the Matrix-designed digital publishing platform, called KORA (Rehberger et al. 2018a). Other scholars were invited to join the 
meetings, and other experts were consulted, including (in a general order of importance): Matthew S. Hopper, Katrina Keefer, Andrew Pearson, Sharla Fett, Patrick Harries, Kyle Prochnow, Paul Lovejoy, Sean Kelley, Edward Alpers, among others. ${ }^{8}$ Project participants from Matrix included: Seila Gonzalez Estrecha, Austin Truchan, Anthony D'Onofrio, among students listed on Matrix's website, although who specifically did what and when is not entirely clear despite efforts to discover. Matrix used Basecamp to keep a record of agendas, discussions, submitted data and other materials related to project development.

Originally, the hard-coded website operated around a structure relative to the location of courts and cases, which usually involved the capture of a slave ship in the Voyages database and the trial resulting in the emancipation of people on board. However, some cases did not involve slaving voyages, but rather coastal slave barracks or captured canoes transporting enslaved Africans along the coast or in the British Caribbean. On 20 July 2016, Gish, who left Matrix shortly after, was consulted and she sketched a relational database scheme for Liberated Africans (Figure 2).

Figure 2. Initial sketch of the Liberated Africans relational databases scheme (20 July 2016)

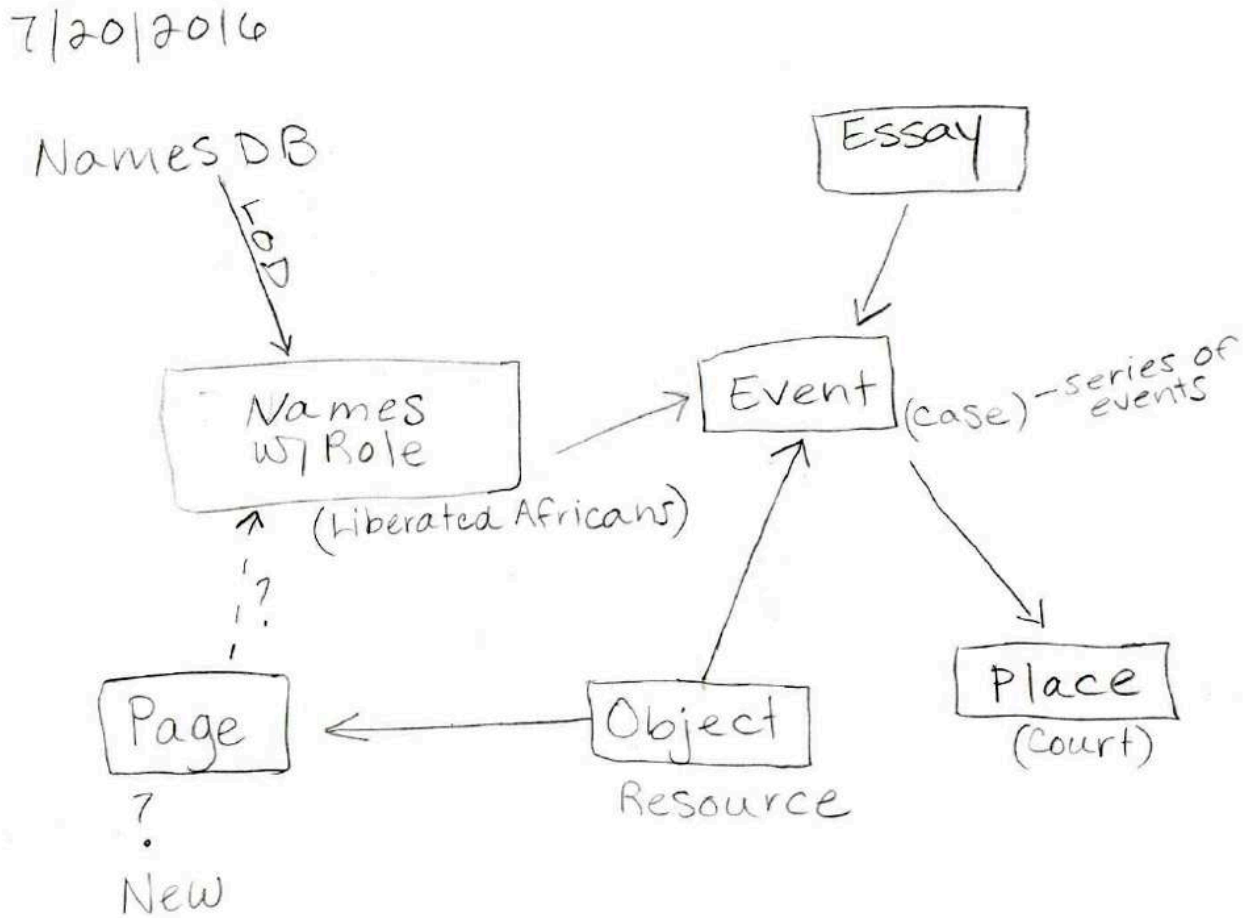

Each box in the above diagram represents a specific spreadsheet of available data obtained from my HTML coded design of Liberated Africans. The core-team of historians initially had difficulty understanding and accepting this proposed concept, which deviated from the original website structure based on cases mostly involving voyages. It was clear that data scientists interpreted the available historical data differently than historians. Out of Gish's sketch, and during subsequent meetings, the relational database structure emerged into four key spreadsheets:

- People, which hosts definitive records for each person with a unique ID, whether registered or not. Content accommodates variations of data obtained from the Registers of Liberated Africans. 
- Events, which includes pivotal information about the date an activity happened to an individual. At present, these data mostly revolve around slave voyages and trial proceedings, such as embarkation, capture, disembarkation, trial, registration, emancipation, etc. In the future, pre- and post-trial events can be added to link in evidence of: baptisms, military service, post-trial resettlement, education, re-enslavement, second emancipation, marriage, birth of children, death, etc.

- Places, which involves geographic coordinates that are associated or connected with people and events. These data have implications for mapping, visualizations and analysis over space and time.

- Sources, which reflects the digital archive of primary source, multimedia objects, such as PDFs or JPGs. All source metadata adheres to DublinCore standards and any published materials must abide by copyright law. Since all data derive from these digitized materials, each object links into the people, events and places datasets; thus, access to the primary source provides users the capability to verify data accuracy. contributions to backend development. Many ideas and new directions transpired among different combinations of people during many Matrix meetings, and/or in individual communications via email, telephone or in person at conferences and workshops. By the fall of 2016, Sheill compiled a chart for the initial metadata values, which were discussed and altered over months of interactions. On 1 December 2016, I organized a panel, "The Liberated Africans Project: New Developments for the Study of the Abolition of the Atlantic and Indian Ocean Slave Trades", for the African Studies Association conference in Washington D.C. ${ }^{10}$ On 10-12 June 2017, Paul Lovejoy hosted a conference at York University called "Liberated Africans and the Abolition of the Slave Trade" with over twenty participants, which was funded by a SSHRC Connections grant and supported via cost sharing from MSU, University of Colorado Boulder, Universidade do Estado do Rio de Janeiro, University of Worcester, Trent University and York University. ${ }^{11}$ This conference resulted in an edited volume, which is a demonstrable contribution that Liberated Africans has had into a traditional print publication (Anderson \& Lovejoy 2020).

in July 2017 with Anderson, Foley, Sheill, and Williams culmi in a final decision on project metadata values. As specified by the World Wide Web Consortium for Linked Open Data interoperability, the project uses a Resource Description Framework, which incorporates Uniform Resource Identifiers in anticipation of its connectivity into Linked Open Data networks. At this meeting, the numbering system for the "people" dataset was finalized, which was generated as a combination of:

- Case ID Number, which derives from the ID numbers obtained from Voyages as indicated by a $\mathrm{V}$ in front of cases (hence V1266). If the case does not appear in Voyages an abbreviation of the location was assigned, as was a new number (hence SL1 or CU1 or BR1-as in Sierra Leone, Cuba and Brazil). 
- Individual Number, which is a sequential number assigned to people/individuals as they were registered starting at 0001 for each new register/case.

- Source, which is a short reference to a source as a means to resolve differences in variant copies of registers. charts and several months of discussion, resulted in a twenty-page document reflective of how the backend of Liberated Africans operates. Determining metadata values is theoretical, collaborative, time consuming and often goes unnoticed. It is usually challenging to determine who has contributed what components over the course of two years of meetings and interactions with an interdisciplinary team. In the case of Liberated Africans, a core-group of historians (myself, Anderson and Williams) and a core-group of data scientists (Sheill and Foley) defined project values for the four-part relational database scheme (people, events, places and sources). Much as in a monograph or peer-reviewed article, the co-authors of the metadata document interpreted global collections of complex historical data into spreadsheets of rows and columns. Much as in the STEM disciplines, the twenty-page Liberated Africans metadata document might be best published as a stand-alone piece with a first, second, third, fourth, fifth and sixth author with a footnote acknowledging a long list of experts who contributed their time and expertise. There does not yet exist a peer-reviewed journal to publish metadata schemes, which is why the Liberated Africans metadata scheme is published as an attachment herein (see the appendix).

\section{Published datasets}

Since individual scholarly recognition is not typically credited in contributions of data, especially spreadsheets provided by emerging scholars, Liberated Africans recognizes versions of the "Collaborators Bill of Rights" (Anon 2011; Di Pressi et al. 2015; Boyles et al. 2018). Beyond the website's database, Liberated Africans cannot operate without different spreadsheets compiled by different people, which then have to be modified and "cleaned" into the values outlined in the metadata scheme. At first glance, published datasets appear much more tangible in terms of assigning academic credit, but such data are constantly fluctuating and being modified by multiple people. Without doubt, Liberated Africans incorporates, builds upon and expands Eltis' data from Voyages and African Origins, which has involved numerous contributors and revisions since the 1970s. The difference between Liberated Africans and Eltis' projects, however, is that Liberated Africans focuses on the human experiences of the people involved in the judicial process of the suppression of the slave trade, rather than the slaving voyage or interpretations of documented African names. Liberated Africans also goes one step further by linking digital copies of primary sources to the data so that users can verify accuracy of uncertain data for further analysis.

The Cuban dataset produced by the Havana Slave Trade Commission involves forty-four cases and over 10,000 rows (people) with twenty-two columns. Within these data, groups of people experienced similar events, which revolved around forty-four slaving voyages and trials out of more than one hundred total cases in Cuba (Roldán de Montaud 2011). These data diverge from Voyages and African Origins by being based on a more complex numbering system for people, more biographical data, information 
about the capturing ship and crew and additional dates (capture, trial, sentence, registration, etc.). Drawing on the British National Archives and my own digitization efforts, over 750 PDFs were extracted from larger volumes and organized on a case-bycase basis. This process involved generating a document inventory according to DublinCore standards. The sources are connected to the relevant data for people, events and places Sheill revised and cleaned project metadata for interoperability. Although Voyages and African Origins make references to primary sources, digitized copies are not available through either resource.

Improved Sierra Leone data derive from Voyages and African Origins, which have been cross-referenced with digital copies of primary sources from the FO 84 series. As Britain's primary base of operations for the abolition of the slave trade, these data are by far the most voluminous in terms of the overall scope of Liberated Africans. At different periods, five courts operated at Freetown, including a Vice Admiralty Court, and Anglo-Portuguese, Anglo-Spanish, Anglo-Dutch and Anglo-Brazilian Mixed Commissions. Between 1808 and 1871, this judicial network adjudicated over 500 cases and emancipated over 100,000 individuals, 80,000 of whom were registered. Since August 2015, Anderson was also instrumental because he compiled the list of over 500 cases for Sierra Leone, including those cases which did not involve a slaving voyage. He also separated the person data from African Origins, reassigned numbers and added more data, specifically related to resettlements. Between 1 July 2017 and 30 June 2018, the project was awarded a joint NEH and Mellon Foundation fellowship for digital publication to build out Sierra Leone data. Leading up to the website relaunch in March 2018, Eltis' core data was improved by adding more dates and information to the events dataset, especially around the capture of slave ships. Anderson, Érika Melek Delgado and Thomas Garriss assisted in extracting and adding to the inventories of documents from the FO 84 and FO 315 series; and Sierra Leone Public Archives. With the website relaunch, these data and documents were added to Liberated Africans directly through Sheill.

Although most of the Brazilian data involve Voyages data, African Origins does not include lists of enslaved Africans liberated by the Anglo-Portuguese and AngloBrazilian mixed commissions in Rio de Janeiro. The reason for this omission is that African Origins focuses on documented African names for interpretation and the Brazilian registers only recorded Christian names assigned to people in Brazil. In the fall of 2015, Williams compiled a case list of just under one hundred cases, while Cavalheiro transcribed twenty registers amounting to over 7,000 people. Cavalheiro also created an inventory of PDF copies of the registers she digitized from Brazil's Arquivo Nacional in Rio de Janeiro. Again, all data was cleaned before sending it to Matrix for uploading into KORA.

\section{New website design}

Hosted and maintained on Matrix servers, Liberated Africans relies on the programming and design team based at Michigan State University (Matrix 2018). The website's underlying architecture uses KORA3, which is a platform-agnostic content management system based on Apache, MySQL and PHP7. Due to upgrading KORA2 to KORA3 (which occurred during the transition from PHP5.6 to PHP7), Matrix pushed back the relaunch date of Liberated Africans to 15 March 2018. Working closely with Sheill and Foley, 
Matrix's director of programming, Gonzalez Estrecha, and lead KORA developer, D'Onofrio, reprogramed the search and browse pages for frontend access to data. Because Matrix is involved in hosting more than a dozen digital projects, project development and programming bleed in and out of one another. Hence acknowledgement of who did what when on the part of Matrix is complicated.

After less than a year, the initial version of the frontend user-experience of Liberated Africans looked outdated. Despite attempts to preserve some elements, Truchan, Matrix's head designer at the time, redesigned the frontend with Sheill's assistance. The image of the website's logo is taken from the "Flag of an African Slaver" obtained in abolition efforts off the coast of East Africa (Anon. 1862). Using digital skills I obtained at Seneca college, the text, banners, flowcharts, maps and images for the overview, sources, copyright, contributors and the acknowledgement pages were then created. Additional paragraphs of text and a selection of images related to court locations were submitted by Anderson (Sierra Leone), myself (Cuba), Williams (Brazil), Hopper (East Africa), Pearson (St. Helena), Caribbean (Kelley), United States (Fett), the Gambia (Prochnow), and Angola (Vanessa Oliveira); and then later revised for consistency in style.

\section{Conclusion}

Since digital humanities research is slowly gaining momentum, collaborative digital mediums should merit scholarly recognition as research at the same level as traditional, peer-reviewed publications. Best practice in writing and publishing the history of a digital project is to assign credit and recognition to individuals in teams of people. This project history explores the creation of Liberated Africans, where the project data originated from, who produced it, how it was modified, and when that occurred between August 2015 and March 2018. Project histories should truthfully explain different levels of participation, the historiography, digitization efforts, the preparation of multimedia objects, the theorizing of metadata schemes, the compilation of metadata, as well as contributions to front- and backend design. These necessary processes in digital projects, which are naturally collaborative and interdisciplinary, require more understanding, especially for purposes of tenure, promotion and job search committees across all fields in the humanities. Christine L. Borgman explains how the

\footnotetext{
disincentives to share are complex in both the sciences and the humanities, but are being addressed. As the sciences learn how to share data and to share credit for their findings, the humanities can build upon their best practices. Intellectual property constraints remain a major stumbling block, and the considerations vary between the sciences and the humanities (Borgman 2009).
}

Each digital project differs through phases of development, especially as members join and leave the project for myriad reasons. Digital project directors have the responsibility of keeping track of individual contributions, as well as of the intangible theories and methods that went into consolidating a website's design and metadata schemes.

As a final note, this article was written to acknowledge and express my gratitude to the many people who have helped with Liberated Africans. I have, to the best of my ability, summarized and analyzed how Liberated Africans was developed as accurately as 
possible. Building a digital resource is interdisciplinary, collaborative and full of abstract contributions. The difficulty of assigning credit in hindsight is that publishing digital project histories can easily overlook contributions no matter how big or how small.

\section{Digital Collections}

DigitAL MiCROFILM PROJECT, 2018. British National Archives. Available online: http:// www.nationalarchives.gov.uk/help-with-your-research/research-guides/free-online-recordsdigital-microfilm/ [last accessed, July 2020].

FOREIGN OFFICE 84 SERIES (FO 84), 1816-42. "Slave Trade Department and Successors: General Correspondence before 1906," British National Archive. Available online: http:// discovery.nationalarchives.gov.uk/details/r/C7404 [last accessed, July 2020]. ELTIS David (dir.), et al., 2018a. African Origins. Available online: http://african-origins.org_[last accessed, February 2018].

ELTIS, David (dir.), et al., 2018b. Voyages: The Trans-Atlantic Slave Trade Database. Available online: http://www.slavevoyages.org [last accessed, July 2020].

HANDLER, Jerome S., \& Michael TUITE, 2018. Slavery Images: A Visual Record of the African Slave Trade and Slave Life in the Early African Diaspora. Available online: http://www.slaveryimages.org [last accessed, July 2020].

LANDERS, Jane, Daniel GENKINS, Kara SCHULTZ, Angela SUTTON, et al., 2018. Slave Societies Digital Archive, Nashville, Vanderbilt University. Available online: https://www.vanderbilt.edu/esss/ index.php [last accessed, July 2020].

REHBERGER, Dean, (dir.), et al., 2018. KORA: The Digital Repository and Publishing Platform, East Lansing, Matrix, The Center for Digital Humanities \& Social Sciences. Available online: http:// kora.matrix.msu.edu/promo_index.php [last accessed, July 2020].

\section{Bibliography}

ANDERSON, Richard, Alex BORUKI, Daniel DOMINGUeS DA SILVA, David ELTIS, Paul LACHANCE, Philip MISEVICH \& Olatunji OJO, 2013. "Using African Names to Identify the Origins of Captives in the Transatlantic Slave Trade: Crowd-Sourcing and the Registers of Liberated Africans, 1808-1862," History in Africa, No. 40/1, pp. 165-91. DOI: https://doi.org/10.1017/hia.2013.3.

ANDERSON, Richard, \& Henry B. LOVEJOY (eds.), 2020. Liberated Africans and the Abolition of the Slave Trade, 1807-1896, Rochester, Rochester University Press. 
ANON., 1862-1866. "Flag of an African Slaver," National Maritime Museum, Greenwich. Available online: https://collections.rmg.co.uk/collections/objects/2002.html [last accessed, July 2020]. ANON., 2011. “Collaborators' Bill of Rights," Off the Tracks: Laying New Lines for Digital Humanities Scholars. Available online: mcpress.media-commons.org/offthetracks/part-one-models-forcollaboration-career-paths-acquiring-institutional-support-and-transformation-in-the-field/acollaboration/collaborators\%E2\%80\%99-bill-of-rights/ [last accessed, July 2020].

ANON., 2015. "From Dust to Digital: Millions of Images from the World's Endangered Archives Made Available," British Library. Available online: https://www.bl.uk/press-releases/2015/ february/endangered-archives-programme-10-years [last accessed, July 2020].

BEHRENDT, Stephen D., 1988. "A Commercial History of the British Slave Trade, 1785-1806: A Preliminary Study," M.A. Thesis, University of Wisconsin-Madison.

BEHRENDT, Stephen D., 1993. “The British Slave Trade, 1785-1807: Volume, Profitability and Mortality," Ph.D. Thesis, University of Wisconsin-Madison.

BORGMAN, Christine L., 2009. "The Digital Future is Now: A Call to Action for the Humanities," Digital Humanities Quarterly, No. 3/4. Available online: http://digitalhumanities.org:8081/dhq/vol/ 3/4/000077/000077.html [last accessed, July 2020].

BOYLES, Christina, Anne CONG-HUYEN, Carrie JOHNSTON, Jim MCGRATH, \& Amanda PHILliPS, 2018. "Precarious Labor and the Digital Humanities," American Quarterly, No. 70/3, pp. 693-700. CURTIN, Philip D., 1969. The Atlantic Slave Trade: A Census, Madison, University of Wisconsin Press. DI PRESSI, Haley, Stephanie GORMAN, Miriam POSNER, Raphael SASAYAMA, \& Tori SCHMITT, 2015. “A Student Collaborators' Bill of Rights," HumTech Blog, Los Angeles, Center for Digital Humanities. Available online: https://humtech.ucla.edu/news/a-student-collaborators-bill-of-rights/ [last accessed, July 2020].

ELTIS, David, 1977. “The Export of Slaves from Africa, 1821-1843,” The Journal of Economic History, No. 37/2, pp. 409-33.

ELTIS, David, 1982. "Nutritional Trends in Africa and the Americas: Heights of Africans, 18191839," The Journal of Interdisciplinary History, No. 12/3, pp. 453-75.

ELTIS, David, 1986. "Slave Departures from Africa, 1811-1867: An Annual Time Series," African Economic History, No. 15, pp. 143-71.

ELTIS, David, 1987. Economic Growth and the Ending of the Transatlantic Slave Trade, New York / Oxford, Oxford University Press.

ELTIS, David, 2018a. “About this Project," in David ELTIS (dir.), et al., “African Origins”. Available online: http://african-origins.org/about [last accessed, February 2018].

ELTIS, David, 2018b. "Acknowledgments," in David ELTis (dir.), et al., "Voyages: The Trans-Atlantic Slave Trade Database”. Previously available online: http://www.slavevoyages.org/about/ acknowledgements [last accessed, February 2018].

ELTIS, David, 2018c. "History of the Project," in David ELTis (dir.), et al., "Voyages: The TransAtlantic Slave Trade Database". Previously available online: http://www.slavevoyages.org/ about/history [last accessed, February 2018].

ENDANGERED ARCHIVES PROGRAMME (EAP), 2009. "Before the War, After the War: Preserving History in Sierra Leone," British Library. Available online: https://eap.bl.uk/project/EAP284 [last accessed, July 2020]. 
ENDANGERED ARCHIVES PROGRAMME (EAP), 2011. "Nineteenth Century Documents of the Sierra Leone Public Archives," British Library. Available online: https://eap.bl.uk/project/EAP443 [last accessed, July 2020].

ENDANGERED ARCHIVES PROGRAMME (EAP), 2015. "Preserving Nineteenth-Century Records in the Sierra Leone Public Archives," British Library. Available online: https://eap.bl.uk/project/EAP782 [last accessed, July 2020].

HANDLER, Jerome S., 2018. “The Making of Slavery Images," in Jerome S. HANDLER \& Michael TUITE, "Slavery Images: A Visual Record of the African Slave Trade and Slave Life in the Early African Diaspora". Available online: http://www.slaveryimages.org/s/slaveryimages/page/history [last accessed, July 2020].

KAHN, Andrew, \& Jamelle BOUIE, 2015. “The Atlantic Slave Trade in Two Minutes," Slate Magazine. Available online: http://www.slate.com/articles/life/the_history_of_american_slavery/2015/06/ animated_interactive_of_the_history_of_the_atlantic_slave_trade.html [last accessed, July 2020]. KIRSCHENBAUM, Matthew G., 2009. “Done: Finishing Projects in the Digital Humanities," Digital Humanities Quarterly, No. 3/2. Available online: http://www.digitalhumanities.org/dhq/vol/ 3/2/000037/000037.html [last accessed, July 2020].

LOVEJOY, Henry B., 2009. “The Registers of Liberated Africans of the Havana Slave Trade Commission: Transcription Methodology and Statistical Analysis," African Economic History, No. 38, pp. 107-35.

LOVEjoY, Henry B., 2015. "Liberated Africans of the Havana Slave Trade Commission: Introductory Documentary”. Available online: https://www.youtube.com/watch?v=KlI9zF6GCcI [last accessed, July 2020].

NWOKEJI, G. Ugo, \& David ELTIS, 2002a. "Characteristics of Captives Leaving the Cameroons for the Americas, 1822-37," The Journal of African History, No. 43/2, pp. 191-210.

NWOKEJI, G. Ugo, \& David ELTIS, 2002b. “The Roots of the African Diaspora: Methodological Considerations in the Analysis of Names in the Liberated African Registers of Sierra Leone and Havana," History in Africa, No. 29, pp. 365-79.

POSNER, Miriam, 2016. "Here and There: Creating DH Community," in Matthew K. GOLD \& Lauren F. KLEIN (ed.), Debates in the Digital Humanities 2016, Minneapolis, University of Minnesota Press, n.p.

RABEN, Joseph, 2007. “Tenure, Promotion and Digital Publication," Digital Humanities Quarterly, No. 1/1. Available online: http://www.digitalhumanities.org/dhq/vol/001/1/000006/000006.html [last accessed, July 2020].

ROLDÁN DE MONTAUD, Inés, 2011. "En los borrosos confines de la libertad: El caso de los negros emancipados en Cuba, 1817-1870," Revista de Indias, No. 71, pp. 159-92.

SHERIDAN, John, 2017. “The Generation Game: Evolving with the Digital Record," British National Archives. Available online: http://blog.nationalarchives.gov.uk/blog/generation-game-evolvingcope-digital-record/ [last accessed, July 2020].

WILLIFORD, James, 2010. "Gross Injustice: The Slave Trade by the Numbers," Humanities: The Magazine for the National Endowment for the Humanities, No. 31/5. Available online: https:// www.neh.gov/humanities/2010/septemberoctober/feature/gross-injustice [last accessed, July 2020]. 


\section{NOTES}

1. The policies and procedures for tenure and promotion in the Department of History at the University of Colorado Boulder requires two peer-reviewed publications in addition to the digital project. One of these supplementary publications should be analytical and the other a project history.

2. David Eltis' conference presentation at Harvard University, "Slave Voyages and African-Origins since 2010: Problems, Retrospectives and Reassessments," "New Research on the Atlantic Slave Trade," 2 October 2015.

3. Based on the following search criteria from the "Estimates" page: 1501-1866 and embarked/disembarked.

4. It should be acknowledged that the descriptions of Voyages I quote herein have since changed and no longer exist online; hence I cite the version I accessed in February 2018.

5. Email with Paul Lovejoy, 19 February 2018.

6. Personal communication with Paul Lovejoy, 20 February 2018.

7. As is common practice, historians often share their digital collections and I am pretty sure I have forgotten someone's name. My apologies. It is also worth noting that each scholar's trajectory to digitize records has involved similar trajectories to my own, which have involved different grants and research projects too numerous to list here.

8. It is also highly likely and plausible that other team members consulted with one another or elsewhere without my knowledge.

9. Email with Dean Rehberger, 21 February 2018.

10. African Studies Association annual conference. Washington DC (2016). Papers: Anderson, "Freetown's Anti-Slave Trade Courts and "Liberation" in the British Atlantic"; Hopper, "Freedom Without Equality: Liberated Africans in the Indian Ocean World"; Williams, "Africanos into Africanos Livres in Nineteenth Century Brazil". Panel chaired by Kristin Mann with Hawthorne serving as the discussant.

11. Conference participants included: Rosanne Adderley, Nielson Bezerra, Maciel Henrique Carneiro da Silva, Maria Clara Carneiro Sampaio, Daniella Cavalheiro, José C. Curto, Walter Hawthorne, Érika Delgado, Daniel Domingues da Silva, Aboubacar Fofana, Matthew S. Hopper, Allen Howard, Katrina Keefer, Sean Kelley, Martin A. Klein, Richard Anderson, Kyle Prochnow, Robert Murray, Sharla Fett, Vanessa Oliveira, Jane Landers, Henry Lovejoy, Paul Lovejoy, Philip Misevich, Andrew Pearson, Dean Rehberger, Maeve Ryan, Inés Roldán de Montaud, Christopher Saunders, Suzanne Schwarz, Randy Sparks, Tim Soriano, David Trotman, Bruno Véras, Daryle Williams, Dan Yon, among other graduate students in attendance. 


\section{ABSTRACTS}

Using the example of Liberated Africans (www.liberatedafricans.org/), this paper examines the difficulties of citing, and assigning credit for, highly collaborative digital humanities research projects in the context of tenure, promotion and the job market. This digital history project traces the lives of tens of thousands of individuals the British recaptured during their efforts to suppress and abolish the slave trade leaving Africa after 1807. The creation, development, release and relaunch of new versions of open source websites and digital archives sometimes build and expand upon the historiography, archival digitization efforts, metadata development, previously published datasets, and often other digital projects. The creation, expansion and relaunch of Liberated Africans would not have been possible without the international and interdisciplinary collaboration and contributions of historians, archivists, computer programmers, digital humanities centers, graduate research assistants and granting agencies. This paper discusses the collaborative process involved in the relaunch of the second version of Liberated Africans in 2018 and serves as an example of how a timestamped project history can assess and recognize individual contributions within a major digital research project which depends on the involvement and input of an interdisciplinary network. This digital project history discusses the many contributors to the historiography, efforts to digitize primary source materials, initial website design, website redevelopment and dataset contributions. It is argued that the publishing of project histories is best practice for understanding the distinction between individual research contributions and service contributions within the burgeoning area of digital humanities research. Without opportunities to publish project histories in peer reviewed journals, digital projects might not be acknowledged as meaningful research contributions and might not receive the same recognition as traditional print publications.

Partant de l'exemple des Liberated Africans (www.liberatedafricans.org/), cet article examine les difficultés rencontrées pour créditer les nombreux chercheurs qui participent aux projets de recherche en humanités numériques, projets qui sont hautement collaboratifs, dans le contexte de la titularisation, de la promotion et du marché du travail. Notre projet d'histoire numérique retrace la vie de dizaines de milliers d'individus quittant l'Afrique que les Britanniques ont « recapturés » au cours de leurs efforts pour supprimer et abolir la traite des esclaves après 1807. La création, le développement, la publication et la mise à jour de nouvelles versions de sites Internet open source contribuent parfois à la construction et au développement de l'historiographie, à l'effort de numérisation des archives, au développement des métadonnées, d'ensembles de données publiés antérieurement, ainsi qu'à d'autres projets numériques. La création, le développement et la mise à jour de Liberated Africans n'auraient pas été possibles sans la collaboration et contribution, tant à l'échelle internationale que sur le plan interdisciplinaire, des historiens, archivistes, programmeurs informatiques, centres de sciences humaines numériques, assistants de recherche diplômés et organismes financeurs. Cet article examine le processus collaboratif qui a permis le lancement de la deuxième version de Liberated Africans en 2018 : cet historique de projet horodaté fait ainsi figure d'exemple de la façon dont on peut évaluer et reconnaître les contributions individuelles au sein d'un grand projet de recherche numérique impliquant la contribution d'un réseau interdisciplinaire. On s'intéresse ici à la multiplicité des contributions quant à l'historiographie, aux efforts de numérisation des matériaux sources, à la conception initiale du site Internet, à son nouveau développement et aux contributions de l'ensemble des données. Selon nous, la publication de l'historique des projets est la meilleure pratique permettant de comprendre l'articulation entre les contributions individuelles de la recherche et les contributions de services dans le domaine de la recherche en 
humanités numériques - un domaine en plein essor. Sans publication de cet historique dans des revues évaluées par les pairs, les projets numériques pourraient ne pas être reconnus comme des contributions significatives à la recherche et ne pas recevoir la même reconnaissance que les publications imprimées traditionnelles.

A partir del ejemplo de Liberated Africans (www.liberatedafricans.org/), este artículo examina las dificultades para consignar la participación de numerosos investigadores en proyectos de investigación de humanidades digitales altamente colaborativos con vistas a la titularización, la promoción y el mercado laboral. Este proyecto de historia digital rastrea la vida de decenas de miles de personas recapturadas por los británicos mientras intentaban suprimir y abolir la trata de esclavos que salieron de África después de 1807. La creación, el desarrollo, la publicación y la actualización de nuevas versiones de sitios web y archivos digitales de código abierto constituyen a veces aportes para la historiografía, el esfuerzo de digitalización de archivos, el desarrollo de metadatos, de conjuntos de datos publicados anteriormente, así como de otros proyectos digitales. La creación, el desarrollo y la actualización de Liberated Africans no hubieran sido posibles sin la colaboración internacional e interdisciplinaria y las contribuciones de historiadores, archivistas, programadores, centros de humanidades digitales, asistentes de investigación de posgrado y agencias de subvención. Este artículo discute el proceso de colaboración que permitió el lanzamiento de la segunda versión de Liberated Africans en 2018. El repaso de la historia de un proyecto fechado sirve para ejemplificar de qué manera es posible evaluar y reconocer las contribuciones individuales dentro de un importante proyecto de investigación digital que depende de la participación y el aporte de una red interdisciplinaria. Nos interesamos aquí por la multiplicidad de las contribuciones, en términos de historiografía, los esfuerzos realizados respecto a la digitalización de materiales de fuentes primarias, el diseño inicial del sitio web, su nuevo desarrollo y las contribuciones al conjunto de los datos. Tal como se argumenta, la publicación de historias de proyectos digitales es la mejor práctica tratándose de comprender la articulación entre las contribuciones individuales de la investigación y las contribuciones de servicios dentro del área floreciente de la investigación en humanidades digitales. Sin oportunidades para publicar historias de proyectos en revistas evaluadas por pares, los proyectos digitales podrían no ser reconocidos como contribuciones de investigación significativas y podrían no recibir el mismo reconocimiento que las publicaciones impresas tradicionales.

Usando o exemplo de Liberated Africans (www.liberatedafricans.org/), este artigo examina as dificuldades encontradas para creditar os investigadores que participam nos projetos de pesquisa em humanidades digitais, sendo estes projetos altamente colaborativos, no contexto da titulação, da promoção e do mercado de trabalho. Este projeto de história digital rastreia a vida de dezenas de milhares de indivíduos que deixaram a África e que os Britânicos « recapturaram » durante seus esforços para suprimir e abolir o trato de escravos depois de 1807. A criação, o desenvolvimento, a publicação e a atualização de novas versões de sites Internet open source podem contribuir para construir e desenvolver a historiografia, para reforçar a digitalização de arquivos, para o desenvolvimento dos metadados, e de conjuntos de dados publicados anteriormente, além de outros projetos digitais. A criação, o desenvolvimento e a atualização de Liberated Africans não teriam sido possíveis sem a colaboração e a contribuição, tanto na escala internacional quanto no plano interdisciplinar, de historiadores, arquivistas, programadores, centros de humanidades digitais, assistentes de investigação e agências de fomento. Este artigo examina o processo colaborativo, que permitiu o lançamento da segunda versão de Liberated Africans em 2018 : este processo serve assim como exemplo do modo como podemos avaliar e reconhecer as contribuições individuais no seio de um grande projeto de investigação digital, que envolve a contribuição de uma rede interdisciplinar. Consideramos aqui a multiplicidade das contribuições para a historiografia, os esforços de digitalização das fontes, a concepção inicial do 
site Internet, o seu recente desenvolvimento e as contribuições do conjunto dos dados. Conforme discutido aqui, a publicação do processo histórico dos projetos é a melhor maneira para entender a articulação entre as contribuições individuais da pesquisa e as contribuições de serviços no âmbito da pesquisa em humanidades digitais - uma área em expansão. Sem a publicação destes históricos de projetos em revistas avaliadas por duplo-cego, os projetos digitais poderiam não ser reconhecidos como contribuições significativas para a investigação, e não receber o mesmo reconhecimento que as publicações impressas tradicionais.

\section{INDEX}

Mots-clés: archives numériques, diaspora africaine, esclavage, abolition, titularisation et promotion

Palabras claves: archivos digitales, diáspora africana, esclavitud, abolición, titularización y promoción

Keywords: digital archives, African diaspora, slavery, abolition, tenure and promotion

Palavras-chave: arquivos digitais, diáspora africana, escravatura, abolição, titulação e promoção

\section{AUTHOR}

HENRY B. LOVEJOY

Assistant Professor, Department of History, University of Colorado Boulder, United States 